IRA-International Journal of Management \& Social Sciences

ISSN 2455-2267; Vol.06, Issue 01 (2017)

Pg. no. 60-66

Institute of Research Advances

http://research-advances.org/index.php/RAJMSS

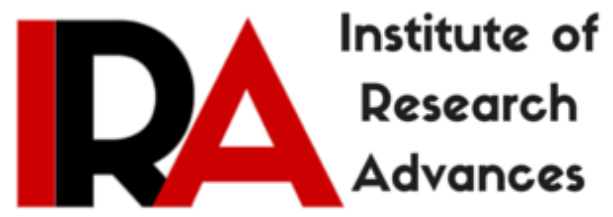

\title{
Contribution of Top Management of Business Organization in Promoting Social Harmony
}

Harsha Sahu

Assistant Professor

Dept. of Management Studies,

Guru Ghasidas Vishwavidyalaya, Bilaspur (C.G.), India.

Type of Review: Peer Reviewed.

DOI: http://dx.doi.org/10.21013/jmss.v6.n1.p9

\section{How to cite this paper:}

Sahu, H. (2017). Contribution of Top Management of Business Organization in Promoting Social Harmony. IRA-International Journal of Management \& Social Sciences (ISSN 2455-2267), 6(1), 60-66. doi:http://dx.doi.org/10.21013/jmss.v6.n1.p9

(C) Institute of Research Advances

(cc) EY-NC

This work is licensed under a Creative Commons Attribution-Non Commercial 4.0 International License subject to proper citation to the publication source of the work.

Disclaimer: The scholarly papers as reviewed and published by the Institute of Research Advances (IRA) are the views and opinions of their respective authors and are not the views or opinions of the IRA. The IRA disclaims of any harm or loss caused due to the published content to any party. 


\begin{abstract}
Management is the process of reaching organizational goals by working with people and other resources. Or knowing what you want people to do, and then getting them to do it the best way. Management is not only practiced in organization and business entities, but management plays an important role in our daily lives and is practiced by every individual is some or the other way. Management is a continuing process, and managers are always involved in it. It helps them to accomplish their objectives. Man is a social being. But within each social group there may be heterogeneous traits and features. So each organization can be thought of as pluralistic and need social harmony for peaceful co-existence. Management can contribute towards social harmony by building- up cordial industrial relationships, ensuring better life and welfare to employee's increasing employees' participation over decisions within the workplace. Consequently, employees will take more interest and initiative in the work assigned. They will feel that they are the vital element of the organization and the organization belongs to them. This will generate the sense of belongingness and loyalty towards the organization. The peaceful co-existence of people from different levels of management can create pleasant and harmonious atmosphere in the organization. The purpose of the study is to investigate how the strong and efficient top level management of the organization can contribute in encouraging social harmony in the workplace. The paper took into account the positive strategies adopted by top management for promoting social harmony in the organization and its implication on the employees, productivity and the economy of the organization. The research methodology is based on the secondary data which include compilation of research article of the experts in the field and the reflections of the essays and article published in the websites. The approach of the study is exploratory in nature.
\end{abstract}

KEYWORDS: Management, Managers, Organization, Productivity and Social harmony.

\title{
MANAGEMENT:
}

Management is the administration of an organization, whether it is a business, a not-for-profit organization, or government body. Management includes the activities of setting the strategy of an organization and coordinating the efforts of its employees or volunteers to accomplish its objectives through the application of available resources, such as financial, natural, technological, and human resources.

Management is concerned with human beings whose behavior is highly unpredictable. Ever since people began forming groups to achieve goal, they could not achieve as individuals. Hence, it is also an academic discipline, a social science whose objective is to study social organization.

Management is an essential function to improve one's life and relationships. Management is therefore everywhere and it has a wider range of application. Based on this, management must have humans, communication, and a positive enterprise endeavor. At first, one views management functionally, such as measuring quantity, adjusting plans, meeting goals. This applies even in situations where planning does not take place. From this perspective, Henri Fayol (1841-1925) [Henri Fayol was one of the most influential contributors to modern concepts of management] considers management to consist of six functions:

1. Forecasting

2. Planning

3. Organizing

4. Commanding

5. Coordinating

6. Controlling 
In the 21 st century observers find it increasingly difficult to subdivide management into functional categories in this way. Instead, one tends to think in terms of the various processes, tasks, and objects subject to management. Branches of management theory also exist relating to nonprofits and to government: such as public administration, public management, and educational management. Many of the assumptions made by management have come under attack from business-ethics viewpoints. As one consequence, workplace democracy (sometimes referred to as Workers' self-management) has become both more common and advocated to a greater extent. All management embraces to some degree a democratic principle - in that in the long term, the majority of workers must support management. Otherwise, they leave to find other work or go on strike. Hence the basic ideas regarding scientific management developed include the following:

- Selecting, training, and developing workers

- Developing a spirit of cooperation between workers and management to ensure that work is carried out in accordance with devised procedures.

- Dividing work between workers and management in almost equal shares, with each group taking over the work for which it is best fitted.

While management trends can change speedily, the long term trend in management has been defined by a market accepting diversity. Managers are currently being trained to encourage greater equality for minorities and women in the workplace, by offering increased flexibility in working hours, better retraining, and innovative (and usually industry-specific) performance markers. Managers designed for the service sector are being trained to use unique measurement techniques, better worker support and more charismatic leadership styles. Human resources find it increasingly working with management in a training capacity to help collect management data on the success or failure of management actions with employees.

\section{SOCIAL HARMONY:}

Social harmony is the peaceful optimistic interaction of people's dynamics. Social Harmony is a very complex and dynamic term wherein there occurs the addition of the word social as well as harmony. Harmony relates to something in the agreement that is fitting the parts into the connected whole which gives the sense of completeness and wholeness. The term social denotes something pertaining to the society wherein societal interaction, diversity, unity, belongings etc. is taken into account. When applied to the industry or organization, it becomes industrial/organizational harmony.

Industrial/organizational harmony refers to a friendly and cooperative agreement on working relationships between employers and employees for their mutual benefit (Laden, 2012). According to Puttapalli and Vuram (2012), industrial/organizational harmony is concerned with the relationship between management and employees with respect to the terms and conditions of the employment and the work place. In effect, it is a situation where employees and management cooperate willingly in pursuit of the organization's aims and objectives. The dimensions of the social harmony in the organization completes with the mutual trust, faith, believe, understanding, ethical behavior, cooperation, coordination, collaboration, commonness, helpfulness, peacefulness etc.

Industrial/organizational harmony requires that:

All management personnel understand their responsibilities and what is required of them, and have the training and authority necessary to discharge such duties and responsibilities efficiently;

$>$ Duties and responsibilities for each group of employees are stated with clarity and simplicity in the organizational structure; 
$>$ Individual employees or work-groups know their objectives and are regularly kept informed of progress made towards achieving them;

$>$ There is an effective link in the interchange of information and views between senior management and members of the work group;

$>$ Employers cooperate with trade unions in establishing effective procedures for the negotiation of terms and conditions of employment and for the settlement of disputes;

$>$ Employers encourage the establishment of effective procedures among member organizations for the settlement of grievances and disputes at the level of the establishment or undertaking, and

$>$ The organization maintains a communication system which secures the interchange of information and views between different levels in the organization and ensures that employees are systematically and regularly kept informed, factually and objectively, of changes and progress in the system.

Industrial/organizational harmony therefore covers four broad areas of cooperation: responsibilities, employment policy, collective bargaining, communication and consultation. Industrial/organizational harmony enhances labor productivity and in turn improves performance in the education sector, achieving economic growth, and enhancing living standards and quality of life. It creates a peaceful working environment conducive to tolerance, dialogue and other alternative (to strike) means of resolving Industrial/labor disputes in Nigeria (such as negotiation, mediation, arbitration, conciliation and litigation or court adjudication) (Laden, 2012). This creates a high level of employee satisfaction.

The fact to use the term social harmony in the business organization presumes that there are many socially conflicting groups at work. An organization should find a mechanism for a compromise among all the competing elements within the business. Social harmony is a must for the organization so that it grows. For growth of a business, managers need to ensure peace as business cannot grow in constant war and struggle.

\section{STRATEGIES ADOPTED BY TOP MANAGEMENT OF ORGANIZATION IN PROMOTING SOCIAL HARMONY AT WORKPLACE:}

A number of strategies have been adopted by top management to enhance industrial harmony and improve productivity in the workplace. Owen (1979) argued that industrial democracy is concerned with the ways of enabling employees within an industrial enterprise to participate in and influence those decisions about the running of the enterprise which affect them. Ozon-Eson (2006) explained that a more comprehensive framework of cooperation between employers and employees in an organization is the scheme of industrial democracy. Industrial democracy can involve a number of arrangements. These arrangements are the strategies employed by organizations to achieve industrial harmony. They are discussed below:

\section{Profit Sharing}

Profit sharing refers to the various incentive plans set up by most organizations that provide direct or indirect payments to employees in addition to employees ${ }^{\text {ee }}$ regular salary and bonuses (Nwokocha, 2014). It involves aligning organizational interest with the financial well - being of the employees (Peter, 2010). The purpose of profit sharing in an organization is to share the financial success of the organization and encourage employee's identity with company success, and further help to keep employees engaged, motivated and satisfied and also turns each employee into an entrepreneur (Chris, 2012). The top management in organizations can explore this scheme to enhance industrial harmony. This is because the scheme definitely provides a sense of satisfaction, self-worth and further foster employee identification with the organization's success. 


\section{Joint Consultation Committee}

This method involves the establishment of a joint committee of management and workers. The committee meets from time to time to deliberate on issues relating to the organization. Such meetings provide the workers the access to any critical information relating to the organization. Muidi (2011) noted that the joint consultation committee entails the direct involvement of individual employees in decisions relating to their immediate work organizations and to the indirect involvement in the decision-making, through representatives in the wider socio-technological and political structure of the organization. The application of this strategy to an extent has helped managers in the organization to achieve industrial peace. This is because it helps to secure employees' satisfaction and stifle grief in the organization.

\section{Participation/Broadening of Collective Bargaining}

This is another form of industrial democracy which is expressed through the framework of collective bargaining. Okene (2008) defines collective bargaining as a process that involves consultation and negotiation of terms and conditions of employment between employers and workers through their representatives. The process involves the making of web of rules and procedure for the organization (Elijah, 2004). Inferring from these definitions, collective bargaining provides an effective window for the resolution of employment issues in organizations through widening the scope of consultation, open and broad-based communication, workers' participation in decision making, etc. Hence, top management in the organizations should utilize it as one of their strategies in ensuring industrial harmony.

\section{IMPACT OF TOP MANAGEMENT'S STRATEGIES IN DEVELOPING SOCIAL HARMONY:}

The significance of management in contributing social harmony in the organization can be discussed in terms of the following points:

\section{* Cordial industrial relations:}

Top management by employing above techniques can develop cordial industrial relation, ensure a better life and welfare of employees and raise the morale through suitable incentives. Consequently, employees will have the feeling that they are the key constituent of the organization and this will as a result generate the sense of belongingness and loyalty towards the organization.

\section{* Motivate employees:}

It can motivate employees to take more interest and initiative in the work assigned and contributes to raising productivity and profitability of the enterprise. The share of profitability will be shared by every stakeholder of the business organization. This will bring the mutual trust and harmony in the business.

\section{* Increase Staff Participation:}

Admirable management will focus on interpersonal relationships in the workplace. Businesses which give the staff more influence over decisions within the workplace will be successful in creating harmony in the organization.

\section{* Sound organization:}

A dynamic and progressive management will guarantee the development of sound organization, which can face any situation - favorable or unfavorable with ease and confidence. This will reduce labor turnover and absenteeism and ensure continuity in the business activities and operations. Sound organization will confirm peaceful atmosphere. 


\section{* Essentials for Prosperity of Society:}

Efficient management clubbed with above strategies will lead to better economical production, which in turn will help to increase the welfare of employees. Top management can make a difficult task easier by avoiding wastage of a scarce resource. This will improve the standard of living and increases the profit which is beneficial to business and society will get maximum output at minimum cost by creating employment opportunities which will generate income in the hands. The organization will come with new products and researches beneficial for society.

\section{* Fulfilling Social responsibilities:}

Well-organized management not only acts as guidelines for achieving organizational objectives, but also guides the managers to perform social responsibilities. For example, the principle of fair remuneration insists on adequate salary to employees and takes care of interest of employees also. Fair treatment guarantees peacefulness in the organization.

\section{* Effective administration:}

Administration is the function of top level management. In this function major plans and policies are formed. Management through above strategies can make administration more effective by discouraging personal prejudices and biases. It will assist in evading clashes and disputes in the organization. So, all the above strategies will definitely assist management in bringing effective and efficient administration which certifies synchronization and harmony in the organization.

\section{* Stability and prosperity:}

Efficient management coupled with above strategies will bring long term success, stability and prosperity to a business enterprise through cooperation and team spirit among employees.

\section{CONCLUSION:}

Efficient management is one of the basic ingredients in the effective operation of an organization given the propensity for periodic conflict in human relationships. Productive management sets the stage for industrial harmony and the realization of the organization's objectives. An efficient management is thus central to maintaining healthy work relationships among personnel. In order to ensure that top management of the organization does not pose any unnecessary challenges, an excellent management should be coupled with social harmony. Social Harmony is the dynamic term which relates to the peaceful commonness among the multicultural, multidimensional and multi-diverse groups. Here all the stakeholders of the organization take part into and contribute towards harmonization so that it could optimistically promote sustainable organizational development. Top management of the organization may employ techniques like collective bargaining, joint consultation committee, profit sharing, etc. to promote, encourage harmony in the organization. Social harmony between management and workers or unions facilitates not only a settlement of disputes or disagreements, but also the avoidance of disputes which may otherwise arise. At the industry level the relationship between employers' organizations and representatives of workers enables them to effectively participate in labor-management relations policy formulation and to arrive at a consensus. It creates an efficient administration, motivates employees, and brings stability and prosperity of the organization as well as society. Every organization needs strong management to run successfully and management can be considered strong and effective if and only if they employ best practices to promote social harmony/organizational harmony in the workplace. 


\section{REFERENCES:}

1. Chris, M. (2012). Characteristics of Profit Sharing. (On-line:http://www.smallbusiness.chron.com). Retrieved October 21, 2016

2. Elijah, O. (2004). Strategies Issues on the Dynamics of Industrial Relations. Lagos: Wepoapo Enterprises.

3. Ladan, M.T. (2012). The imperatives of industrial harmony and academic excellence in a productive educational system. A paper presented at the flag-off of the "Do the right thing: Campus focus" students re-orientation programme, organized by the National Orientation Agency, held at the University of Calabar, Cross River State, Nigeria, 13th November, 2012.

4. Muindi, F.K. (2011). The Relationship between Participation in Decision-Making and Job Satisfaction among Academic Staff in the School of Business, University of Nairobi. Journal of Human Resources Management, 1-34.

5. Nwokocha, I.(2015).Employers and the Enhancement of Industrial Harmony in Private Sector Organizations in Nigeria, in Port Harcourt,Rivers State, Nigeria. IOSR Journal Of Humanities And Social Science, 20(5), 28-35

6. Nwokocha, I. Sustainable Managerial Strategies for Employee Retention in Two Private Sector Organizations in Port Harcourt, Rivers State, Nigeria. Unpublished Ph.D Thesis, Ebonyi State University, 2014.

7. Okene, O.V.C. (2008). Collective Bargaining, Strikes and the Quest for Industrial Peace in Nigeria Nigerian Journal of Labour Law and Industrial Relations, 2(2), 39-66.

8. Owen, T. (1979). The Manager and Industrial Relations. Oxford: Pergamon Press.

9. Ozon-Eson, P.I. (2006). Role of Employers in Enthroning Harmony During Transformation and Industrial Turbulence. A Paper presented at Nupeng National Workshop. Benin, Edo State. 31 August to 3rd September, 2006.

10. Peter, V.B. (2010). How to build Profit Sharing Plan. (On-line:http://www.inc.com). Retrieved, October 21, 2016.

11. Puttapalli, A.K. \& Vuram, I.R. (2012). Discipline: The tool for industrial harmony. International journal of multidisciplinary educational research, 1(1), $146-151$.

12. www.studymode.com

13. http://www.managementparadise.com/forums/articles/42525-importance-management.html

14. https://answers.yahoo.com/question/index?qid=20101222014659AAb7VzJ

15. http://iasdream.com/role-of-local-self-governments-in-promoting-social-harmony/

16. https://in.answers.yahoo.com/question/index?qid=20071230025644AApFz98

17. https://in.scribd.com

18. https://in.creativeheadconsultantsindia.blogspot.com

19. https://in.slideshare.net

20. https://in. businessdictionary.com

21. https://in. encyclopedia2.thefreedictionary.com

22. https://in.managementstudyguide.com

23. http://www.ehow.com/info_8419159_importance-management-theories-managing-people.html

24. https://en.wikipedia.org/wiki/Management

25. http://www.yourarticlelibrary.com/organization/the-importance-of-management-principles-for-anorganisation/8622/

26. https://in.coursehero.com

27. https://in.cliffsnotes.com

28. https://in.termpaperwarehouse.com

29. https://in.ijern.com

30. https://in.iosrjournals.org

31. https://in.eajournals.org

32. https://in.ijsre.com 